\title{
PEMERIKSAAN STATUS GIZI SEBAGAI UPAYA PREVENTIF PENYAKIT DEGENERATIF PADA SISWA SEKOLAH BM JAKARTA PUSAT
}

\author{
Meilani Kumala ${ }^{1}$, David Limanan ${ }^{2}$, dan Alexander Halim Santoso ${ }^{3}$
}

\author{
${ }^{1}$ Bagian Ilmu Gizi, Fakultas Kedokteran, Universitas Tarumanagara Jakarta \\ Email:meilanik@fk.untar.ac.id \\ ${ }^{2}$ Bagian Biokimia Biologi Molekuler, Fakultas Kedokteran, Universitas Tarumanagara Jakarta \\ Email: davidl@fk.untar.ac.id \\ ${ }^{3}$ Bagian Ilmu Gizi, Fakultas Kedokteran, Universitas Tarumanagara \\ Email: alexanders@fk.untar.ac.id
}

\begin{abstract}
These day the number of school-age children who suffer from obesity has doubled compared to 2010. Children who are obese tend to remain obese in adulthood and are at risk of suffering from various non-communicable diseases such as heart and blood vessel disease, metabolic syndrome, diabetes, and others. Based on these conditions in an effort to prevent obesity early which is one of the factors causing non-communicable diseases, it is necessary to check the nutritional status of high school students who are classified as adolescents. Activities include data collection on student identity, snack food patterns, types of snacks, and daily student activities and followed by measurements of body weight, height and waist circumference to get an overview of the nutritional status of students. This dedication activity involved Tarumanagara University Faculty of Medicine students. The results of the examination found that most of the 48 students and 37 students who had been assessed for nutritional status experienced height based on age $(T B / U)$ within normal limits. As many as $34.1 \%$ of adolescents are overweight and overweight. The percentage of overweight and obesity in adolescents is quite large compared to nationally, urban or in DKI Jaya. The mean waist circumference ( $\mathrm{Lp}$ ) $31.25 \%$ of male adolescents were found to be above the normal limit indicating excess fat in the abdominal area, while the average Lp of adolescent girls was still within normal limits. In terms of daily activities which are one of the factors causing obesity, $67.1 \%$ of adolescents engage in sports activities, but many hours are also used to use gadgets, which are about five hours per day. Most (94.1\%) of adolescents consume various kinds of snacks including biscuits, chips, nuts and fruit. Based on the results obtained, it is necessary to assess nutritional status regularly and also counseling about a healthy lifestyle.
\end{abstract}

Keywords: Teenagers; school age; obesity; nutritional status.

\begin{abstract}
ABSTRAK
Dewasa ini jumlah anak umur sekolah yang menderita obesitas mengalami peningkatan dua kali lipat dibandingkan tahun 2010. Anak-anak yang obes cenderung untuk tetap obes di umur dewasa dan berisiko menderita berbagai penyakit tidak menular seperti penyakit jantung dan pembuluh darah, sindrom metabolik, diabetes, dan sebagainya. Berdasarkan keadaan tersebut dalam upaya pencegahan secara dini terjadinya obesitas yang merupakan salah satu faktor penyebab penyakit tidak menular, perlu dilakukan pemeriksaan status gizi pada siswa siswi sekolah menengah atas yang merupakan tergolong umur remaja. Kegiatan meliputi pendataan identitas siswa, pola makanan cemilan, jenis cemilan, dan aktifitas siswa sehari-hari dan dilanjutkan dengan pengukuran berat badan, tinggi badan dan lingkar pinggang untuk mendapatkan gambaran status gizi siswa. Kegiatan pengabdian ini melibatkan mahasiswa Fakultas Kedokteran Universitas Tarumanagara. Hasil pemeriksaan didapatkan bahwa sebagian besar dari 48 siswa dan 37 siswi yang telah dilakukan penilaian status gizi mengalami tinggi badan berdasarkan umur (TB/U) dalam batas normal. Sebanyak 34,1\% remaja mengalami berat badan berlebih dan kegemukan. Persentase kelebihan berat badan dan obesitas pada remaja ini cukup besar dibandingkan secara nasional, perkotaan ataupun di DKI Jaya. Rerata lingkar pinggang (Lp) 31,25\% remaja laki-laki didapatkan sudah di atas batas normal yang menunjukkan adanya kelebihan lemak di daerah perut, sedangkan rerata Lp remaja perempuan masih dalam batas normal. Ditinjau dari aktivitas sehari-hari yang merupakan salah satu fator penyebab kegemukan didapatkan sebesar $67,1 \%$ remaja melakukan aktivitas olah raga, namun tidak sedikit juga waktu yang digunakan untuk menggunakan gadget yaitu sekitar lima jam per hari. Sebagian besar $(94,1 \%)$ remaja mengonsumsi bermacam macam cemilan meliputi biskuit, chips, kacang dan buah. Berdasarkan hasil yang didapat perlu dilakukan penilaian status gizi secara rutin dan juga penyuluhan tentang gaya hidup yang sehat.
\end{abstract}

Kata kunci: Remaja; umur sekolah; obesitas; status gizi. 


\section{PENDAHULUAN}

Seiring meningkatnya taraf kesejahteraan masyarakat, jumlah penderita obesitas cenderung meningkat. Obesitas merupakan penyebab kematian nomor lima di dunia dan mencapai 2,8 juta jiwa per tahun (Beyen et al., 2013) Saat ini obesitas tidak saja menyerang kelompok dewasa, tetapi juga anak(Raj \& Kumar, 2010) dan remaja(WHO, 2017). Berdasarkan data dari WHO tahun 2016, angka kejadian obesitas pada kelompok umur 5-17 tahun, satu dari sepuluh anak mengalami obesitas. Jumlah anak umur sekolah yang menderita obesitas mengalami peningkatan dua kali lipat dibandingkan tahun 2010.(Kosti \& Panagiotakos, 2006) Anak-anak yang mengalami obesitas cenderung untuk tetap obes di umur dewasa(Beyen et al., 2013) dan berisiko menderita berbagai penyakit tidak menular seperti penyakit jantung dan pembuluh darah, sindrom metabolik, diabetes, dan sebagainya(WHO, 2017) Berdasarkan data dari Riset Kesehatan Dasar (Riskesdas) tahun 2013 didapatkan bahwa propinsi DKI Jakarta merupakan propinsi dengan prevalensi gemuk pada anak dan remaja tertinggi (30,1\% dan 4,2\%).(Badan Penelitian dan Pengembangan Kesehatan Kementerian Kesehatan RI, 2013)

Peningkatan kesejahteraan masyarakat berdampak terhadap perubahan gaya hidup seperti aktifitas rendah, pola makan tinggi energi dan rendah serat. Pola makan yang tidak seimbang dengan kurangnya berolahraga diduga penyebab utama obesitas pada remaja.(Kementerian Badan Penelitian dan Pengembangan Kesehatan, 2018; WHO, 2017) Makanan instan menjadi pilihan bagi sebagian besar masyarakat yang terpapar dengan kehidupan modern. Makanan tersebut tidak mengandung komposisi zat gizi seimbang sebagaimana yang dibutuhkan tubuh. Terlebih lagi makanan makanan instan sangat rendah kandungan seratnya.

Sekolah BM yang terletak di Jakarta Utara merupakan salah satu sekolah dengan jumlah siswa yang cukup besar. Total jumlah murid Sekolah BM mulai dari play grup sampai SMA mencapai 900 siswa. Sebagai salah satu upaya mencegah terjadinya dampak obesitas terhadap siswa - siswi sekolah menengah atas (SMA) yaitu di umur remaja, pihak sekolah mengambil langkah meneyelenggarakan pemeriksaan status gizi dan penilaian aktivitas sehari harinya. Terkait kegiatan tersebut, Sekolah BM menyelenggarakan kerjasama dengan Bagian Gizi Fakultas Kedokteran Universitas Tarumanagara mengadakan kegiatan Bakti Kesehatan mencakup pemeriksaan berat badan, tinggi badan, lingkar pinggang, aktivitas sehari-hari dan asupan cemilan untuk siswa-siswi BM. Tujuan kegiatan ini mendapatkan data status gizi dan meningkatkan kesadaran siswa dan siswi Sekolah BM Jakarta Utara untuk selalu menjalan pola makan seimbang dan gaya hidup yang sehat. Diharapkan melalui kegiatan Bakti Kesehatan ini didapatkan data mengenai status gizi dan gaya hidup dan selanjutnya dapat dilakukan upaya-upaya untuk mencegah terjadinya obesitas yang merupakan salah satu factor penyakit tidak menular.

\section{METODE PELAKSANAAN}

Berdasarkan permasalahan yang diuraikan di atas Fakultas Kedokteran Universitas Tarumanagara mengadakan kegiatan pengabdian kepada siswa dan siswi kelas Sekolah BM, Jakarta Utara yang merupakan salah satu perwujudan tridharma perguruan tinggi di bidang Pengabdian dan Pelayanan kepada Masyarakat (P2M). Pada kegiatan bakti kesehatan ini, kami melibatkan peran serta dosen dan mahasiswa.

Kegiatan pengabdian masyarakat ini dilaksanakan dengan melakukan pemeriksaan antropometri meliputi berat badan (BB), tinggi badan (TB), lingkar pinggang (Lp) untuk mendapatkan gambaran status gizi remaja Sekolah BM, Jakarta Utara. Kegiatan dilaksanakan pada Februari 2019, pukul 07.00 - 14.00 WIB di Sekolah BM, Jakarta Utara. Pelakasanaan kegiatan dilakukan dalam tiga ruangan yang masing-masing ruangan berisikan dua unit timbangan berat badan, 
microtoisse untuk mengukur tinggi badan, pita pengukur lingkar pinggang, satu meja pendaftaran dan satu meja untuk pencatatan. Masing-masing ruangan dilengkapi dengan dua dokter dan dua mahasiswa pelaksana

Kepada siswa-siswi dilakukan pendataan identitas yang diperoleh dari pihak sekolah meliputi data gender dan umur. Selanjutnya kepada siswa-siswi dilakukan pengukuran antropometri meliputi BB, TB dan Lp. Pengukuran BB dilakukan menggunakan alat timbangan berat badan dengan ketelitian $0,1 \mathrm{~kg}$. Timbangan BB diletakkan di tempat yang keras, permukaan rata dan jarum timbangan menunjukkan angka nol. Siswa-siswi yang akan ditimbang menggunakan baju seringan mungkin dan tanpa alas kaki atau kaus kaki. Siswa-siswi berdiri di tengah permukaan timbangan dan melihat lurus ke depan, berdiri tegak tanpa dibantu, tenang. Pengukuran TB dilakukan menggunakan microtoisse stature $2 \mathrm{~m}$ dengan ketelitian $0,1 \mathrm{~cm}$ yang digantungkan pada dinding setinggi dua meter dari lantai yang datar. Pada waktu pengukuran, siswa-siswi tanpa alas kaki berdiri pada permukaan datar dan tumit merapat, kepala tegak menempel pada dinding sehingga pandangan tegak lurus dengan sumbu tubuh (Frankfrut plane). Hasil pengukuran TB selanjutnya di plot pada lembar TB terhadap umur (TB/U) grafik WHO 2007. Berdasarkan BB dan TB dapat dihitung indeks massa tubuh (IMT) terhadap umur (IMT/U) untuk mendapatkan status gizinya. Baik hasil plotting TB/U dan IMT/U pada grafik WHO 2007 merupakan data penilaian status gizi siswa siswi. Pengukuran Lp dilakukan menggunakan pita pengukur yang terbuat dari fiber dan tidak elastis. Subjek berdiri tegak dan bernafas normal. Pita pengukur ditempatkan pada titik tengah di antara titik tulang kosta terakhir dengan titik ujung lengkung tulang pangkal paha atau pinggul, kemudian lingkarkan pita ke bagian perut dengan posisi lingkaran sejajar lantai. Pendataan aktivitas siswa-siswi sehari-hari, pola makanan cemilan dan jenis cemilan diperoleh melalui wawancara dengan siswa-siswi menggunakan lembar kuesioner.

\section{HASIL PEMERIKSAAN DAN LUARAN YANG DICAPAI}

Telah dilakukan pemeriksaan antropometri meliputi BB, TB dan Lp pada sejumlah 85 siswa/i dengan rincian sebanyak 48 siswa dan 37 siswi. Rentangan umur siswa-siswi adalah 15-19 tahun dengan jumlah terbesar adalah umur 16 tahun (41,9\%) dan hanya satu siswa yang berumur 15 tahun $(1,2 \%)$. Hasil pemeriksaan antropometri didapatkan rerata berat badan siswa siswi sebesar 66,$02 ; 14,99$ dan rerata tinggi badan adalah 165.72;8.63. Sebaran data demografi siswa siswi BM dapat dilihat pada Tabel 1 .

Tabel 1. Sebaran Data Siswa/Siswi Sekolah BM Berdasarkan Jenis Kelamin, Umur dan Antropometri

\begin{tabular}{lll}
\hline Variabel & Jumlah $(\mathbf{n})$ & $\mathbf{X} ;$ SD \\
\hline Jenis Kelamin & 85 & \\
$-\quad$ Laki-laki & 48 & \\
$-\quad$ Perempuan & 37 & \\
Umur $(\mathrm{n}=85)$ & & 16,$82 ; 0,87$ \\
$-\quad$ Laki-laki & & 16,$73 ; 0,89$ \\
$-\quad$ Perempuan & 16,$95 ; 0,84$ \\
Berat badan $(\mathrm{kg})(\mathrm{n}=85)$ & 65,$74 ; 14,85$ \\
$-\quad$ Laki-laki & & 73,$64 ; 12,66$ \\
$-\quad$ Perempuan & 55,$49 ; 10,69$ \\
Tinggi badan $(\mathrm{cm}) \mathrm{X} ;$ SD & & 165,$67 ; 8,67$ \\
$-\quad$ Laki-laki & 171,$55 ; 12,66$ \\
$-\quad$ Perempuan & 158,$05 ; 4,97$ \\
\hline
\end{tabular}


Hasil penilaian status gizi berdasarkan IMT/U menunjukkan sebagian besar $(65,9 \%)$ siswa-siswi mempunyai status gizi normal dan 29 siswa-siswi mengalami berat badan berlebih serta kegemukan. Berdasarkan TB/U didapatkan hanya satu $(1,2 \%)$ siswi yang mengalami tinggi badan kurang dibanding rerata tinggi badan pada umur yang sama.

Data status gizi orang tua siswa-siswi diperoleh berdasarkan hasil wawancara dengan siswasiswinya. Hasil pendataan didapatkan sebagian besar mempunyai status gizi tidak gemuk. Berdasarkan lingkar pingang (Lp) didapatkan rerata siswa siswi mempunyai Lp dalam batas normal. Remaja laki-laki mempunyai rerata Lp dalam batas normal $(<90 \mathrm{~cm})$ namun terdapat 15 $(31,25 \%)$ siswa mempunyai Lp di atas normal. Rerata Lp perempuan dalam batas normal $(<80$ $\mathrm{cm}$ ) namun terdapat satu siswi mempunyai Lp yang kecil $59 \mathrm{~cm}$ dan $6(16,21 \%)$ siswi mempunyai Lp di atas rerata batas normal. Sebaran status gizi berdasarkan TB/U dan IMT/U, status gizi orang tua dan Lp siswa siswi dapat dilihat pada Tabel 2 dan Gambar 1.

Tabel 2. Sebaran Status Gizi Berdasarkan TB/U dan IMT/U, Status Gizi Orang Tua, Lingkar Pinggang Siswa Siswi

\begin{tabular}{ccc}
\hline \multicolumn{1}{c}{ Variabel } & Jumlah n $(\%)$ & X ; SD \\
\hline - TB/U & & 97,$81 ; 3,28$ \\
$-\quad$ Kurang $(70-89 \%)$ & $1(1,2)$ & \\
$-\quad$ Normal $(90-110 \%)$ & $84(98,8)$ & 22,$7 ; 4,0$ \\
IMT/U & $56(65,9)$ & \\
$-\quad$ Normal & $19(22,4)$ & \\
$-\quad$ Overweight & $10(11,8)$ & \\
- Obesitas & & \\
Status gizi orang tua & $23(27,1)$ & \\
- Gemuk & $61(71,8)$ & \\
- Tidak gemuk & $1(1,2)$ & 78,$85 ; 11,98$ \\
- Tidak mengetahui & & 84,$70 ; 10,61$ \\
Lingkar pinggang (n=85) & & 71,$27 ; 9,13$ \\
- Laki-laki & & \\
- Perempuan & & \\
\hline
\end{tabular}

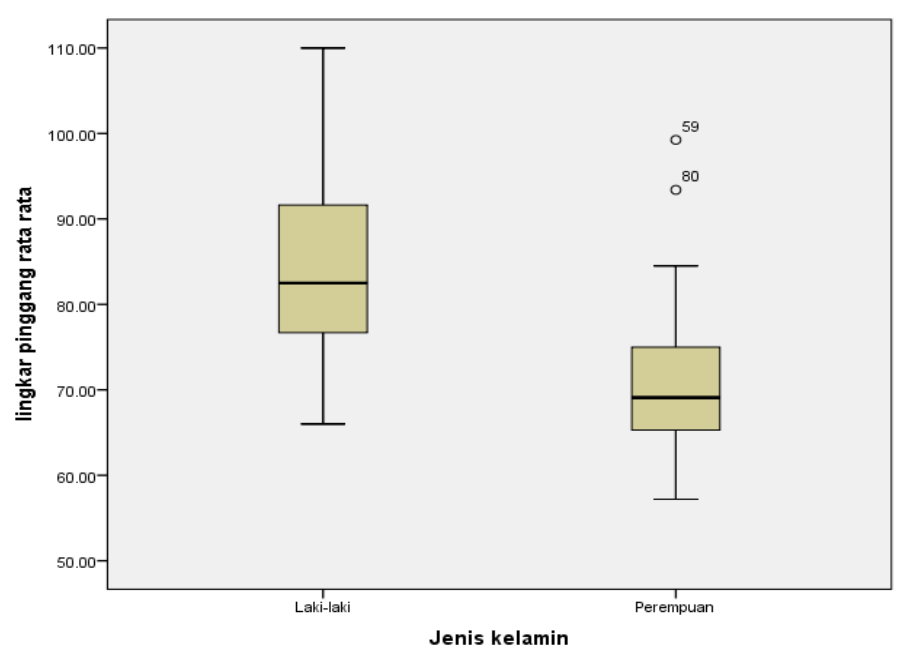

Gambar 1. Sebaran Lingkar Pinggang Siswa Siswi 
Hasil penilaian aktivitas sehari-hari didapatkan sebanyak $57(67,1 \%)$ siswa menyatakan aktif berolah raga secara rutin dan sebanyak 28 (32,9\%) tidak berolah raga secara rutin. Sejumlah siswa/i yang aktif berolah raga mempunyai kebiasaan melakukan olah raga antara $2-4 \mathrm{kali} / \mathrm{minggu}$ dengan jenis olah raga yang tertinggi diminati adalah badminton namun umumnya melakukan lebih dari satu jenis olah raga. Waktu lainnya digunakan sebagian besar siswa/i untuk menggunakan gadget dengan rerata lama penggunaan gadget 313,$87 ; 177,86$ menit per hari.

Tabel 3. Sebaran kegiatan aktivitas/olah raga, frekuensi perminggu dan frekuensi menggunakan gadget

\begin{tabular}{|c|c|c|}
\hline Variabel & Jumlah n (\%) & $\mathrm{X}$; SD \\
\hline \multicolumn{3}{|l|}{ Aktif olah raga } \\
\hline - Rutin & $57(67,1)$ & \\
\hline - $\quad$ Tidak rutin & $28(32,9)$ & \\
\hline \multicolumn{3}{|l|}{ Frekuensi kali/minggu } \\
\hline$-1-3$ & $44(51,8)$ & \\
\hline$-4-6$ & $17(20)$ & \\
\hline - Tidak menjawab & $24(28,2)$ & \\
\hline \multicolumn{3}{|l|}{ Jenis aktivitas/olah raga } \\
\hline - Basket & $6(7,1)$ & \\
\hline - Renang & $4(4,7)$ & \\
\hline - Badminton & $10(11,8)$ & \\
\hline - Fitness & $5(5,9)$ & \\
\hline - Futsal & $1(1,2)$ & \\
\hline - Lainnya & $4(4,7)$ & \\
\hline - $\quad$ Lebih dari 1 & $43(50,6)$ & \\
\hline - $\quad$ Tidak mengisi & $12(14,1)$ & \\
\hline $\begin{array}{l}\text { Rerata Lama } \\
\text { menggunakan gadget/hari } \\
\text { (menit) }(\mathrm{n}=85)\end{array}$ & & $316.43 ; 177.35$ \\
\hline
\end{tabular}

Mengonsumsi cemilan merupakan kebiasaan yang banyak dilakukan siswa siswi dengan lebih dari satu jenis cemilan yang paling banyak dikonsumsi.

Tabel 4. Sebaran asupan dan jenis

\begin{tabular}{|c|c|}
\hline Variabel & Jumlah n (\%) \\
\hline \multicolumn{2}{|l|}{ Asupan cemilan } \\
\hline Ya & $80(94,1)$ \\
\hline - $\quad$ Tidak & $5(5,9)$ \\
\hline \multicolumn{2}{|l|}{ Jenis Cemilan } \\
\hline - Buah & $7(8,2)$ \\
\hline - Biskuit & $4(4,7)$ \\
\hline - Chips & $2(2,4)$ \\
\hline - Coklat & $2(2,4)$ \\
\hline - Kacang & $2(2,4)$ \\
\hline - Lebih dari Satu & $64(75,3)$ \\
\hline - Tidak tau & $4(4,7)$ \\
\hline
\end{tabular}


Pelaksanaan kegiatan dilakukan tepat waktu, berlangsung dengan tertib dan semua siswa- siswi mempunyai antumurs untuk mengetahui hasil pemeriksaan status gizi, antropometri ataupun hasil pengukuran lingkar pinggang. Gambar 2. Pembukaan kegiatan yang dilakukan oleh Dekan FK Untar.

\section{Hasil penilaian status gizi}

Pengukuran berat badan dan tinggi badan (Gambar 3 dan Gambar 4) terhadap umur (TB/U) pada siswa-siswi termasuk baik, hanya satu siswi yang mengalami tinggi badan yang kurang dan persentase ini jauh lebih rendah dibandingkan persentase TB/U hasil Riskesdas 2018 di DKI yaitu mencapai 7,1 \%.7 Rerata IMT/U didapatkan sebesar 34,1\% siswa siswi dalam kategori berat badan berlebih dan kegemukan. Berdasarkan Riskesdas 2018 persentase berat badan berlebih dan kegemukan remaja umur 16 - 18 tahun di DKI didapatkan sebesar 21,1\%, di daerah perkotaan secara nasional sebesar 15,5\% dan secara nasional didapatkan 13,5\%. ${ }^{7}$ Dibandingkan persentase berat badan berlebih dan kegemukan secara nasional, perkotaan dan DKI, maka hasil yang diperoleh pada siswa-siswi ini adalah jauh di atas bahkan mencapai dua kalinya. Hal ini perlu mendapat perhatian asupan makanan, pola makanan dan cemilan serta aktivitas sehari-hari.

Hasil rerata pengukuran Lp baik remaja laki-laki dan perempuan dalam batas normal, namun didapatkan $15(31,25 \%)$ siswa mempunyai Lp di atas normal. Hal ini menunjukkan terdapat obesitas sentral di mana dalam batas status gizi bisa saja normal tetapi terdapat penumpukan lemak dalam rongga perut. Keadaan ini perlu mendapat perhatian karena merupakan salah satu faktor mengalami penyakit tidak menular. Hasil pengukuran Lp siswa siswi ini dibandingkan dengan angka obesitas sentral di Indonesia (15,7\%), angka kejadian obesitas sentral pada remaja ini cukup tinggi mencapai dua kali dari angka nasional. Untuk pengukuran obesitas sentral pada remaja putri didapatkan angka 16,21\% masih di bawah jumlah angka nasional yaitu 46,7\%. Angka nasional dapat saja lebih tinggi karena angka nasional meliputi seluruh populasi di Inonesia dengan umur $\geq 15$ tahun. Walaupun demikian, perlu diperhatikan agar dapat cepat ditangani untuk mencegah terjadinya penyakit tidak menular yang meliputi hipertensi, stroke, diabetes melitus dll.

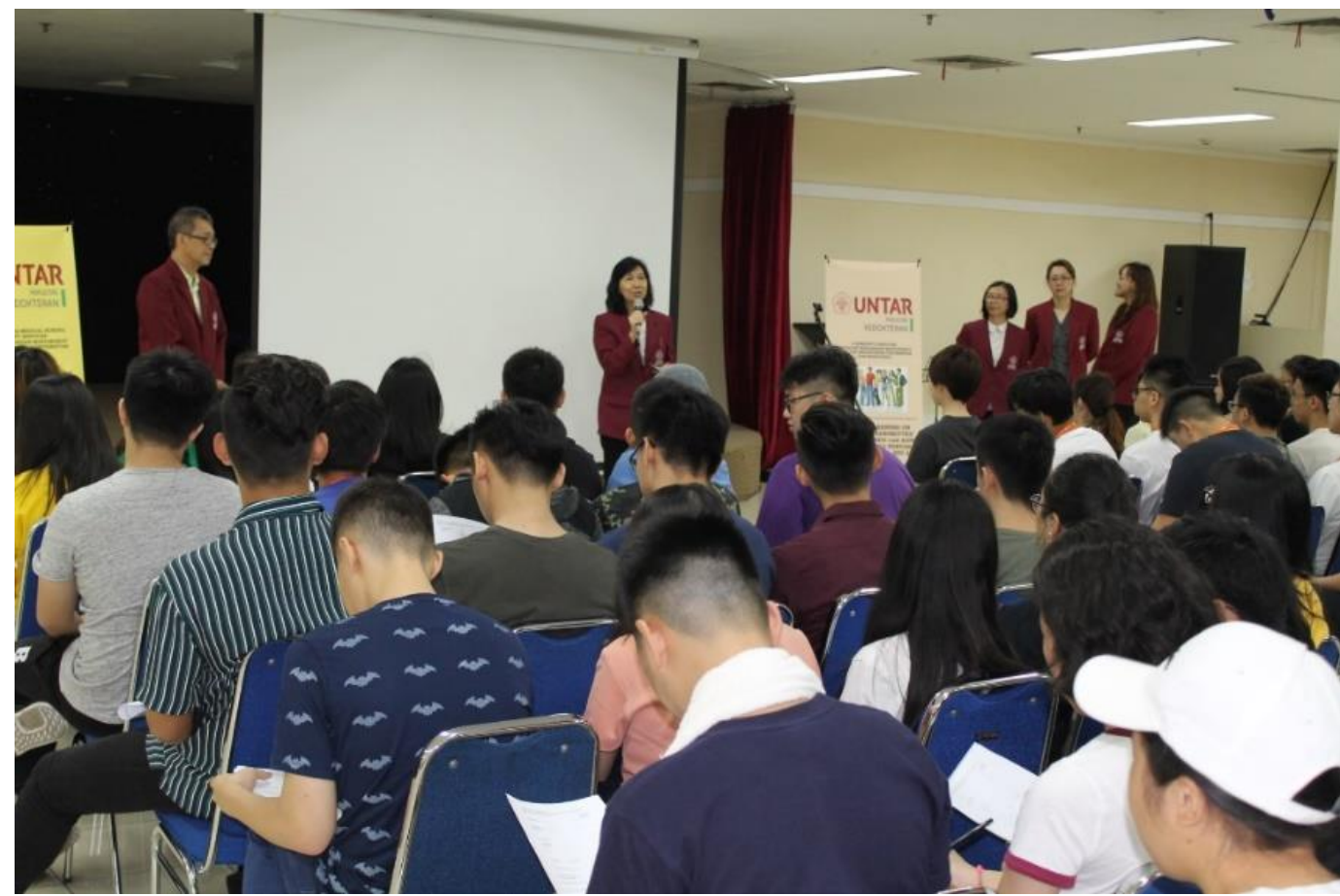

Gambar 2. Pembukaan Kegiatan yang Dilakukan oleh Dekan FK Untar 


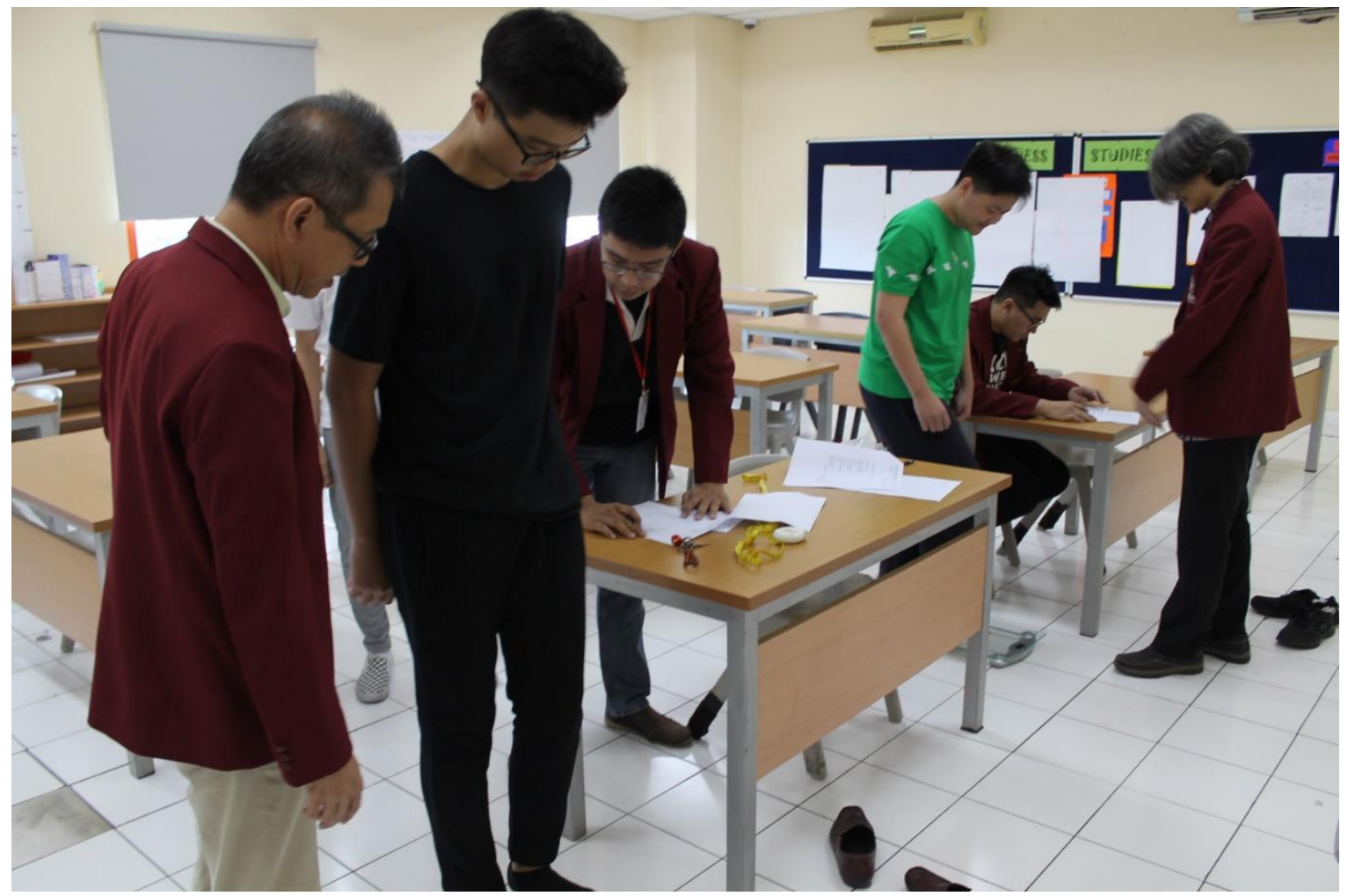

Gambar 3.Pelaksanaan Pengukuran Berat Badan

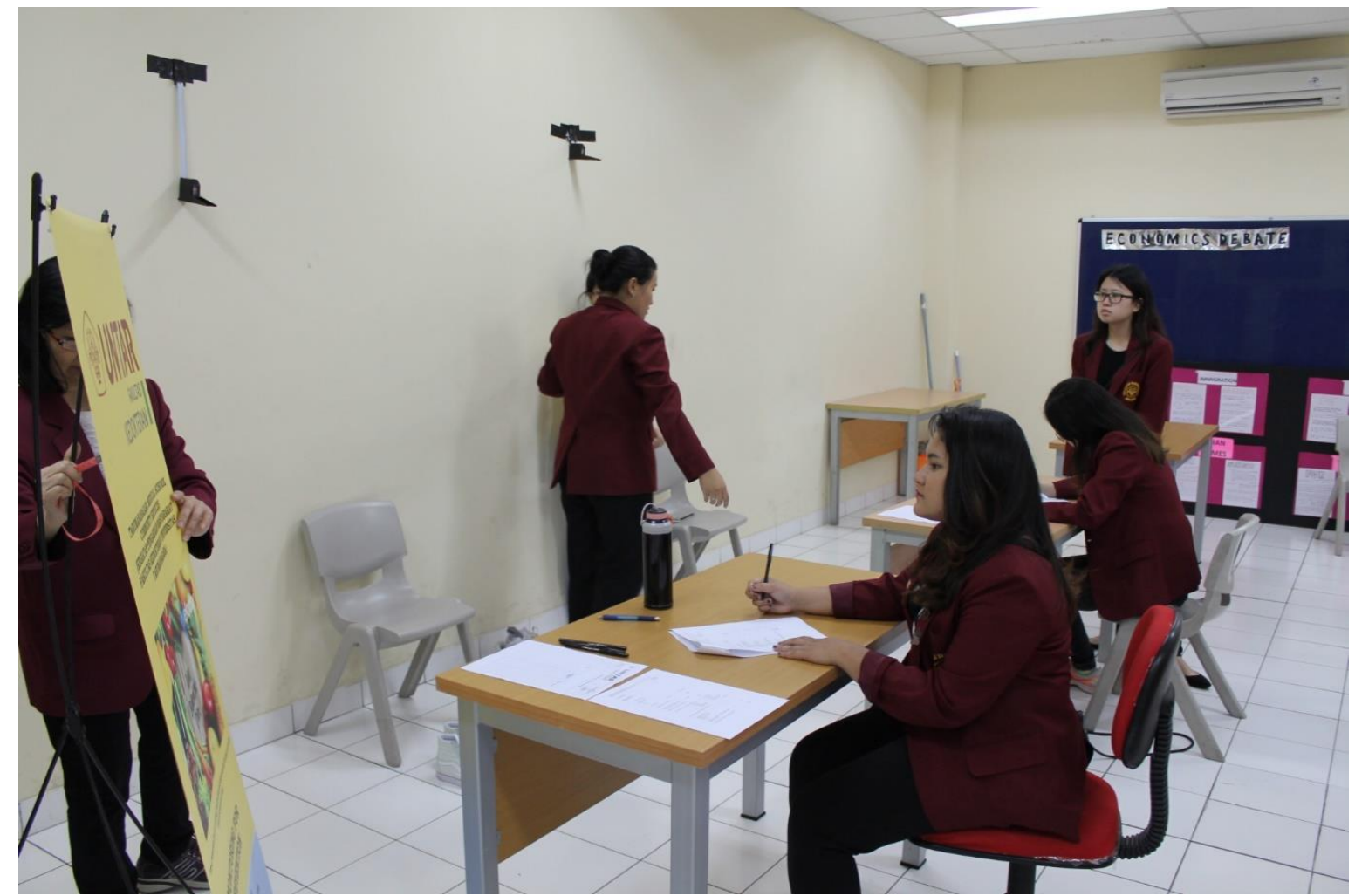

Gambar 4. Pelaksanaan Pengukuran Tinggi Badan 


\section{Hasil Kegiatan dan Aktivitas Sehari-hari}

Penilaian aktivitas atau kegiatan yang dilakukan sehari-hari sudah lebih $(67,1 \%)$ dari separuh siswa/i melakukan aktivitas tapi masih belum merata. Sejumlah siswa/i mempunyai aktivitas olah raga yang cukup baik di mana didapatkan frekuensi aktivitas yang dilakukan 2-4 kali per minggu sebanyak $77,04 \%$. Penggunaan gadget merupakan gaya hidup yang sudah membudaya dewasa ini ternyata juga menjadi gaya hidup remaja ini. Didapatkan rerata penggunaan gadget sehari menghabiskan waktu 316.43;177.35 menit atau berdasarkan perhitungan jam sebanyak kurang lebih lima jam per hari digunakan untuk menggunakan gadget. Waktu yang cukup besar mengurangi kegiatan aktif dari siswa siswi sehari harinya.

Hasil asupan cemilan

Sebagian besar $(94,1 \%)$ siswa siswi mengonsumsi cemilan di antara makan makanan utama dengan cemilan yang beraneka jenisnya. Berdasarkan riskesdas 2013 dinyatakan makanan yang berisiko meliputi makanan/minuman manis, makanan asin, makanan berlemak/kolesterol/gorengan, makanan yang dibakar, makanan daging/ayam/ikan olahan dengan pengawet, bumbu penyedap, soft drink atau minuman berkarbonasi, minuman berenergi, mie instant/makanan instant lainnya. Pada siswa/i ini didapatkan sebagian besar mengonsumsi lebih dari satu macam cemilan. Jenis yang disebutkan meliputi biscuit, chips, coklat, kacang merupakan cemilan dengan tinggi kalori, gula, asin dan lemak kecuali buah. Sebagai upaya mencegah mengalami peningkatan berat badan, lemak di daerah pinggang, dianjurkan menyesuaikan makanan sehari-hari dan juga cemilan yang sehat.

\section{KESIMPULAN DAN SARAN}

Sebagian besar dari 48 siswa dan 37 siswi didapatkan TB/U dalam batas normal dan sebesar 34,1\% siswa/i mengalami berat badan berlebih dan kegemukan. Sebesar 31,25\% lingkar pinggang siswa di atas batas normal dan di atas persentase nasional sedangkan siswinya didapatkan rerata lingkar pinggangnya di bawah jumlah angka nasional. Sebagian besar $(67,1 \%)$ siswa/i melakukan kegiatan dan aktivitas olah raga sehari-hari. Siswa/i sebagian besar meluangkan 316,43;177,35 menit (lima jam) per hari untuk menggunakan gadget. Sebagian besar $(94,1 \%)$ Siswa/i mengonsumsi cemilan dengan jenis cemilan bermacam macam meliputi biskuit, chips, coklat, kacang dan buah. Berdasarkan data yang diperoleh disarankan kepada siswa/i perlu dilakukan pemantauan secara berkala untuk status gizi TB/U, IMT/U, lingkar pinggang, aktivitas sehari-hari dan pola makanan meliputi cemilannya serta mendapat edukasi tentang gaya hidup yang baik.

\section{Ucapan Terima Kasih}

Terima kasih disampaikan kepada Lembaga Penelitian dan Pengabdian kepada Masyarakat (LPPM) Universitas Tarumanagara, yang telah memberikan pendanaan, sehingga terselengaranya PKM ini. Kepada rekan-rekan tim dan para mahasiswa terimakasih juga atas kerjasama dan bantuannya.

\section{REFERENSI}

Badan Penelitian dan Pengembangan Kesehatan Kementerian Kesehatan RI. (2013). RISET KESEHATAN DASAR RISKESDAS 2013. Jakarta. Retrieved from http://www.depkes.go.id/resources/download/general/Hasil Riskesdas 2013.pdf

Beyen, T. K., Gebregergs, G. B., \& Yesuf, M. E. (2013). Overweight and Obesity, and Associated Factors among High School Students in Gondar Town, North West Ethiopia. Journal of Obesity \& Weight Loss Therapy, 03(02), 1-5. https://doi.org/10.4172/21657904.1000165

Kementerian Badan Penelitian dan Pengembangan Kesehatan. (2018). HASIL UTAMA RISKESDAS 2018 Kesehatan, 20-21. 
Kosti, R. I., \& Panagiotakos, D. B. (2006). The epidemic of obesity in children and adolescents in the world. Cent Eur J Public Health, 14(4)(November), 151-159. https://doi.org/10.21101/cejph.b0245

Raj, M., \& Kumar, R. K. (2010). Obesity in children \&amp; adolescents. The Indian Journal of Medical Research, 132(5), 598-607. Retrieved from http://www.ncbi.nlm.nih.gov/pubmed/21150012

WHO. (2017). Childhood overweight and obesity. Retrieved July 14, 2019, from https://www.who.int/dietphysicalactivity/childhood/en/ 